\title{
THE LATE EARLY CRETACEOUS TRANSGRESSION ON THE LATERITES IN VOURINOS AND VERMION MASSIFS (WESTERN MACEDONIA, GREECE)
}

\author{
Photiades A. ${ }^{1}$, and Carras N. ${ }^{1}$ \\ in collaboration with Bortolotti V. ${ }^{2}$, Fazzuoli M. ${ }^{2}$, and Principi G. ${ }^{2}$ \\ I.G.M.E., MessoghionStr.70,11527,Athens,fotiadis@igme.gr,nicarras@igme.gr \\ ${ }^{2}$ Dipartimento di Scienze della Terra, Università di Firenze, ViA La Pira, 4, 50121 Firenze, Italy, \\ milvio@dicea.unifi.it
}

\begin{abstract}
Three stratigraphical sections from eastern Vourinos (Rhodiani area) to eastern Vermion massifs revealed the same age of the laterite events affecting the serpentinized ophiolite complex after its emplacement on the Pelagonian domain. All of them consist from their base upwards of serpentinized harzburgite slivers with lateritic unconformities on the top, followed by transgressive upper Lower Cretaceous neritic limestones.

At Kteni locality (Rhodiani area), a laterite horizon, lying on top of serpentinites, is covered by transgressive neritic limestones with Salpingoporella urladanasi, assigning a Barremian - Albian age, followed by Orbitolinidae limestones. At Tsimodia locality (NNW to the previous), the laterite horizon, lying on karstified Upper Jurassic reef limestones (which are the top member of a carbonate platform body tectonically lying on the ophiolites), is transgressively overlain by iron-rich pisolith levels and Aptian limestones of the wackestone-mudstone type, also containing Salpingoporella urladanasi, followed by Cenomanian Orbitolina limestones.

Finally, the third examined locality, further north-eastward to the previous, is situated at the eastern slopes of Vermion massif, and more precisely at the $N W$ part of Koumaria village. There, it can again be observed that the lateritized serpentinite slivers are overlain transgressively by neritic limestones with Salpingoporella urladanasi, passing upwards into Upper Cretaceous recrystallized limestones with Orbitolinidae and rudist fragments and, finally, to flysch deposition.

These features allow to recognize that the emersion and the consecutive lateritization of the thrust-emplaced ophiolites in Vourinos and Vermion massifs in the northern Pelagonian domain, starting from the Latest Jurassic, was followed by a marine transgression beginning from the Barremian - Albian, firstly under restricted and brackish carbonate platform conditions, marked by the presence of the dasycladalean alga Salpingoporella urladanasi, followed by normal salinity carbonate platform conditions. The neritic sedimentation was stable until the Early Cenomanian. Subsequently, a deepening, earlier at Vourinos and later at Vermion, resulted in deposition of pelagic and turbiditic carbonates and then of flysch.
\end{abstract}

Key words: Stratigraphy, Pelagonian, Salpingoporella urladanasi. 


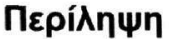

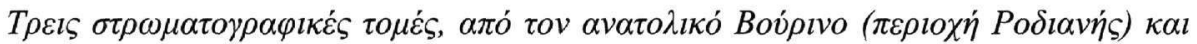

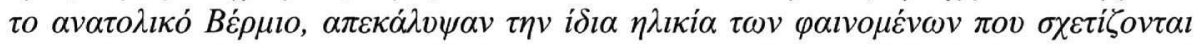

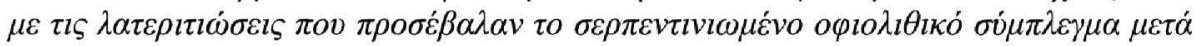

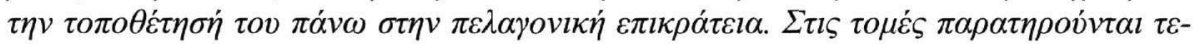

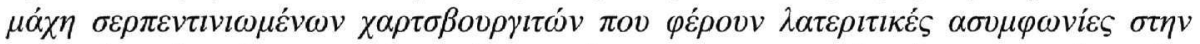

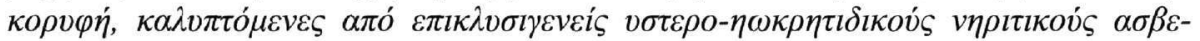

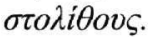

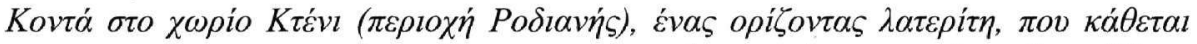

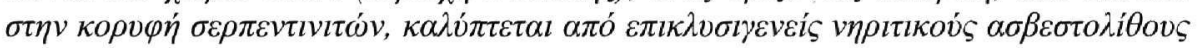

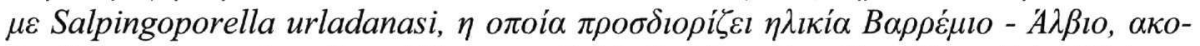

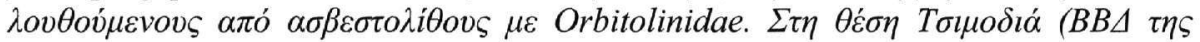

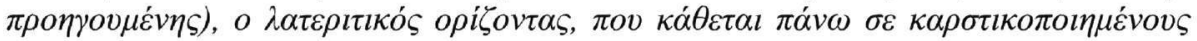

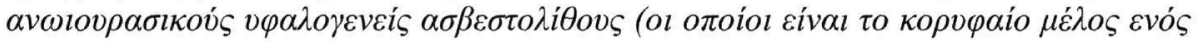

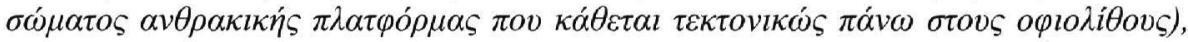

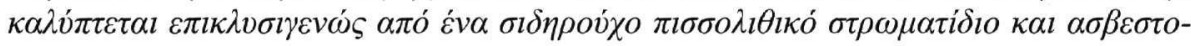

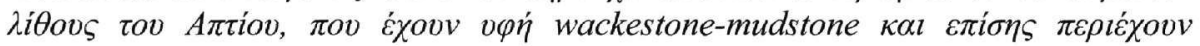

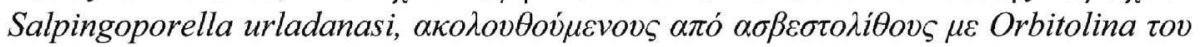
Kevouaviov.

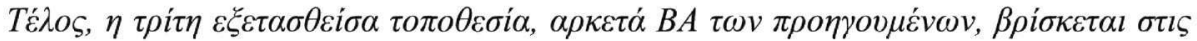

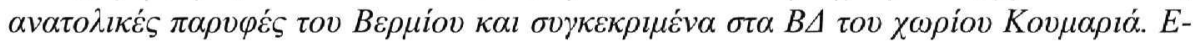

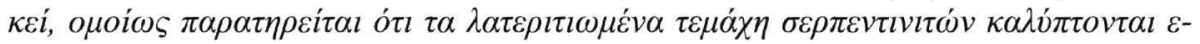

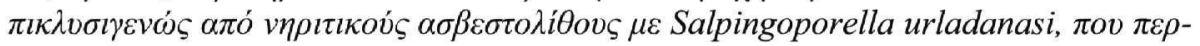

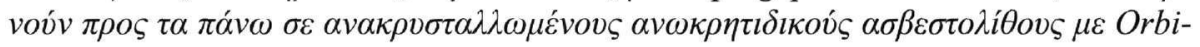

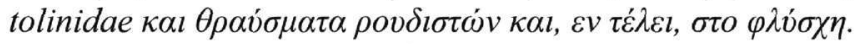

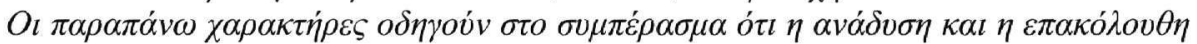

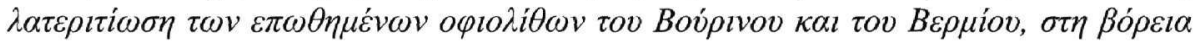

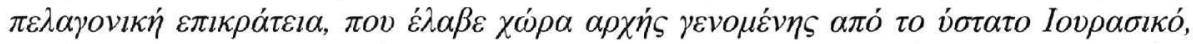

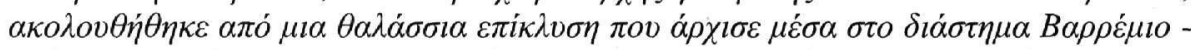

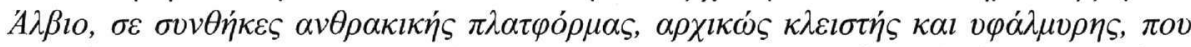

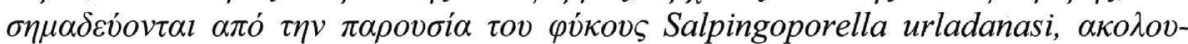

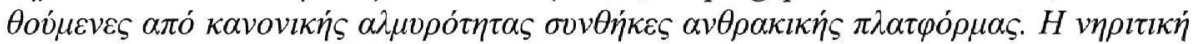

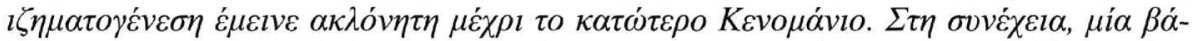

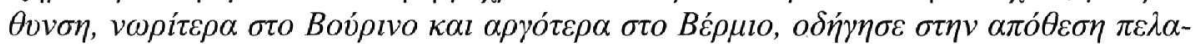

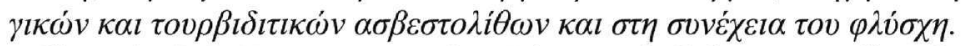

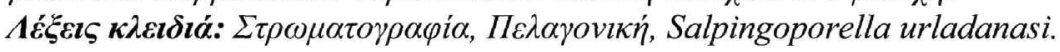

\section{Introduction}

In the Vourinos and Vermion Massifs (Fig.1) two main tectonic units are present: the metamorphic Pelagonian unit (a), consisting mainly of Upper Triassic-Lower Jurassic marbles and the overlying Jurassic schistose melange and the ophiolitic nappe (b), thrusted during the Late Jurassic, consisting mainly of serpentinized harzburgite and dunite slivers (Photiades et al. 1998).

Moreover, on the ophiolites of the Vourinos massif (Rhodiani area), a tectonic wedge-sliver, consisting of limestones of a Middle-Late Jurassic carbonate platform, can also be locally observed. The over-thrusting of this unit on the ophiolites is younger than the Late KimmeridgianTithonian top of the carbonate platform limestones (Bortolotti et al. 2004, Carras et al. 2004).

Both Jurassic limestones and surrounding ophiolites in the Vourinos area and ophiolites in the Vermion area are locally covered by $\mathrm{Fe}-\mathrm{Ni}$ laterite lenses, or a thin lateritic, argilo-pelitic bed (Photiades et al. 1998). 


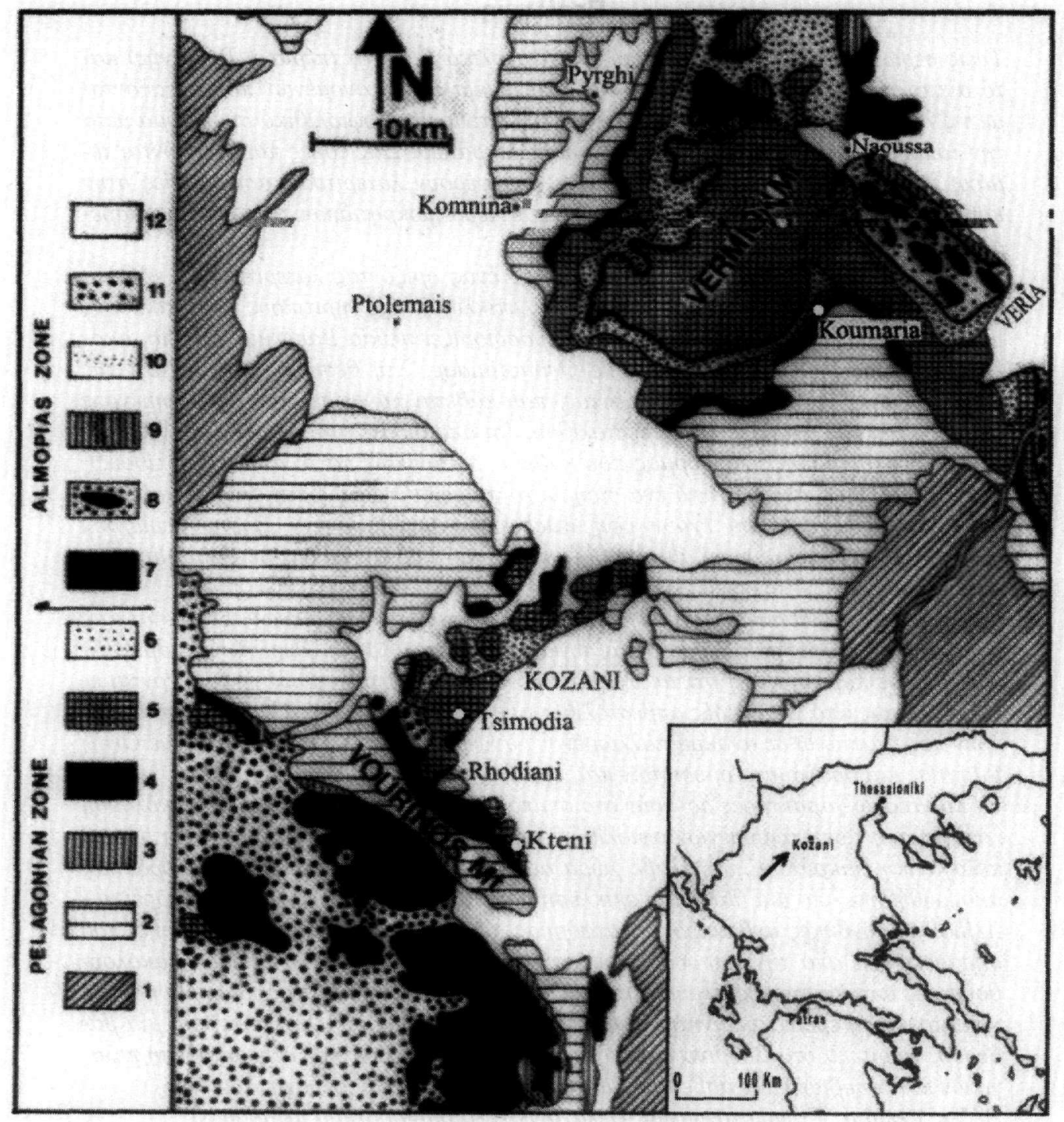

Figure 1 - Geological sketch-map (Brunn, 1956, modified). Key symbols: Pelagonian zone: pre-Alpine basement with gneiss (1); Triassic-Jurassic marble (2); Jurassic schistose melange

(3); serpentinite with laterite (4); Upper Jurassic and/or Upper Cretaceous limestone (5); Upper Cretaceous flysch sequence (6); Almopias zone: serpentinite with basic and acidic rock slivers (7); ophiolitic melange formation (8); Upper Cretaceous deep-water limestone

(9); Upper Cretaceous flysch sequence (10); molasse formation (11); Neogene and Quaternary deposits (12)

This lateritized substratum in the Vourinos-Vermion area is uncomformably covered by the neritic deposits of a "Mid" Cretaceous transgression, overlain by deep marine, mainly turbiditic, carbonate sediments, during the Late Cretaceous (Photiades et al., 1998; Bortolotti et al. 2000 2001, 2002, 2004, Carras et al. 2004), followed by Late Maastrichtian flysch deposition.

The aim of this paper is to show that, apart local particularities, the general modalities and timing of the post-ophiolite-emplacement history in both the Vourinos and Vermion areas, i.e. the Latest 
Jurassic - Earliest Cretaceous emersion and lateritization event and the consecutive marine transgression, were similar.

\section{Stratigraphical data}

\subsection{The Kteni section}

In the Kteni area, at the hill 670 (N $40^{\circ} 9^{\prime} 42,12^{\prime \prime}$; E $21^{\circ} 47^{\prime} 5,88^{\prime \prime}$, Vourinos massif, Fig. 1), the serpentinites, bearing lateritic lenses on the top, are overlain by the following transgressive succession, from bottom upwards (Fig. 2):

1. A calcareous conglomerate, $1,5 \mathrm{~m}$ thick, with pebbles $8-50 \mathrm{~mm}$ in size, coming from Upper Jurassic reef limestones with Tubiphytes morronensis Crescenti, Suppiluliumaella sp. and coral fragments; the matrix is lateritic.

2. A thin-bedded, black, micritic and brecciated limestone with Salpingoporella urladanasi Conrad, Peybernès \& Radoičić and ostracods, lying on the conglomerate, or directly on the substratum. The dasyclad alga $S$. urladanasi is known in usually restricted marine to brackish environments of Barremian - Albian age (Carras et al. in press).

3. A thick bedded limestone of the rudstone type, with Orbitolinidae and angular fragments of packstones and grainstones of carbonate platform facies. The depositional environment is probably a slope and the age probably Cenomanian.

\subsection{The Tsimodia section}

In the Tsimodia area (N 40 $133^{\prime} 35,4^{\prime \prime}$; E $21^{\circ} 43^{\prime} 29,94^{\prime \prime}$, NNW to the previous, Fig. 1), the laterites lie on top of a calcareous body, consisting of Upper Jurassic reef limestones, while the serpentinites crop out downwards in the wider area. The overlying transgressive succession consists, from bottom upwards, of (Fig. 2):

1) A discontinuous level of brown pisolitic limestone, some $\mathrm{cm}$ thick, adhered upon the laterite. The microfacies is a bioclastic wackestone, intensely contaminated by lateritic materials forming pisoids, containing Debarina hahounerensis Fourcade, Raoult \& Vila, Miliolidae, detritus of Salpingoporella sp. [S. cf. muehlbergii (Lorenz)] and mollusk fragments.

2) Above the pisolitic level, or directly on the laterites, a level of brown, thin-bedded, micritic limestones lies, some metres thick. In this level, two types of microfacies have been observed:

- wackestone rich in lateritic mud and Salpingoporella urladanasi Conrad, Peybernès \& Radoičić (Fig. 3).

- mudstone-wackestone rich in lateritic mud, containing Debarina hahounerensis Fourcade, Raoult \& Vila, Palorbitolina lenticularis (Blumenbach), Miliolidae, and cavities with geopetalic filling.

3) The brown limestones are overlain by dark-gray, thin-bedded, micritic limestones, ca. $10 \mathrm{~m}$ thick. The common microfacies is bioclastic wackestone with Palorbitolina lenticularis (Blumenbach) (only in the lower part of the level), Debarina hahounerensis Fourcade, Raoult \& Vila, Vercorsella laurentii (Sartoni \& Crescenti), Pfenderina cf. globosa Foury, "Valvulineria "sp., Glomospira sp., Salpingoporella dinarica Radoičić, Salpingoporella sp., "Bacinella”, Miliolidae.

The age of the levels 1, 2 and the lower part of the level 3 is Early Aptian, because of the presence of Palorbitolina lenticularis and geometrical considerations. The upper part of the level 3 is generally Aptian. 


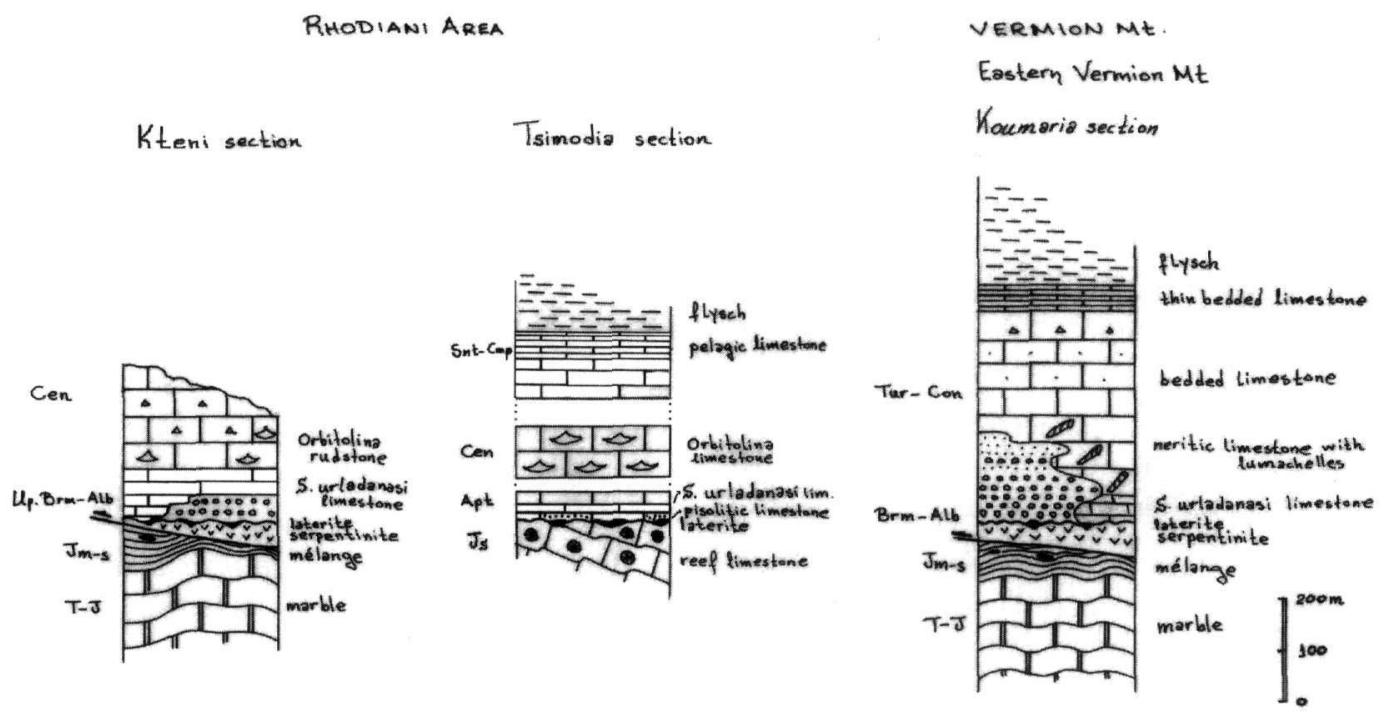

Figure 2 - The stratigraphic columns in the considered sections

4) $30 \mathrm{~m}$ upwards, thick-bedded Orbitolina limestones are observed. The microfacies consists of ramp bioclastic wackestone with Orbitolina (Conicorbitolina) conica (D'Archiac), Orbitolina sp. and "Bacinella" masses (Early Cenomanian).

5) More upwards along the succession, thin-bedded pelagic mudstones with Globotruncana linneiana (D’Orbigny), Marginotruncana pseudolinneiana Pessagno, M. coronata (Bolli), Globigerinelloides sp. and Heterohelicidae (Santonian - Early Campanian) crop out.

This succession reveals the following modalities of the transgression. In the first stage, during the Early Aptian, a carbonate sedimentation environment, contiguous to the still emerged areas and intensely contaminated by lateritic materials, was established; it was composed of various subenvironments, commonly brackish (levels 1 \& 2). The connection with the emerged areas was soon interrupted, already during the Early Aptian (lower part of the level 3) and a carbonate platform was stable up to the Early Cenomanian (levels 3 \& 4). Afterwards, a deeper environment was established, with pelagic sedimentation (level 5).

\subsection{The Koumaria section}

In the Koumaria area (N 40 $32^{\prime} 17,82^{\prime \prime}$; E 22 $2^{\prime} 4,56^{\prime \prime}$, eastern part of the Vermion massif, Fig. 1), the laterites lie directly on the weathered serpentinites (Fig. 2), which are thrust-emplaced on a Pelagonian substratum, consisting (from the base upwards) of a pre-alpine gneiss basement, of detached Triassic-Jurassic marbles, of a chert-bearing bedded marble formation, and of a Jurassic schistose mélange enclosing various sized blocks of amphibolite (Photiades 2004). The transgression on the laterites starts with:

- A body of conglomerates, coarser and wider in the lower part, becoming finer and less extensive upwards. The pebbles originate from the underlying carbonate rocks of the TriassicJurassic metamorphic pelagonian substratum.

- Laterally, the laterites are directly overlain by thick-bedded neritic limestones, which overlie gradually also the conglomerates. The base is commonly represented by recrystallized bioaccumulations (lumachelles) of gastropods and/or bivalves. Some contaminations by metallic oxides can be interpreted as reworked material of the underlying laterites. A sample from the very base contains a detritus of SAlpingoporella urladanasi assigning a Barremian - Albian age. 

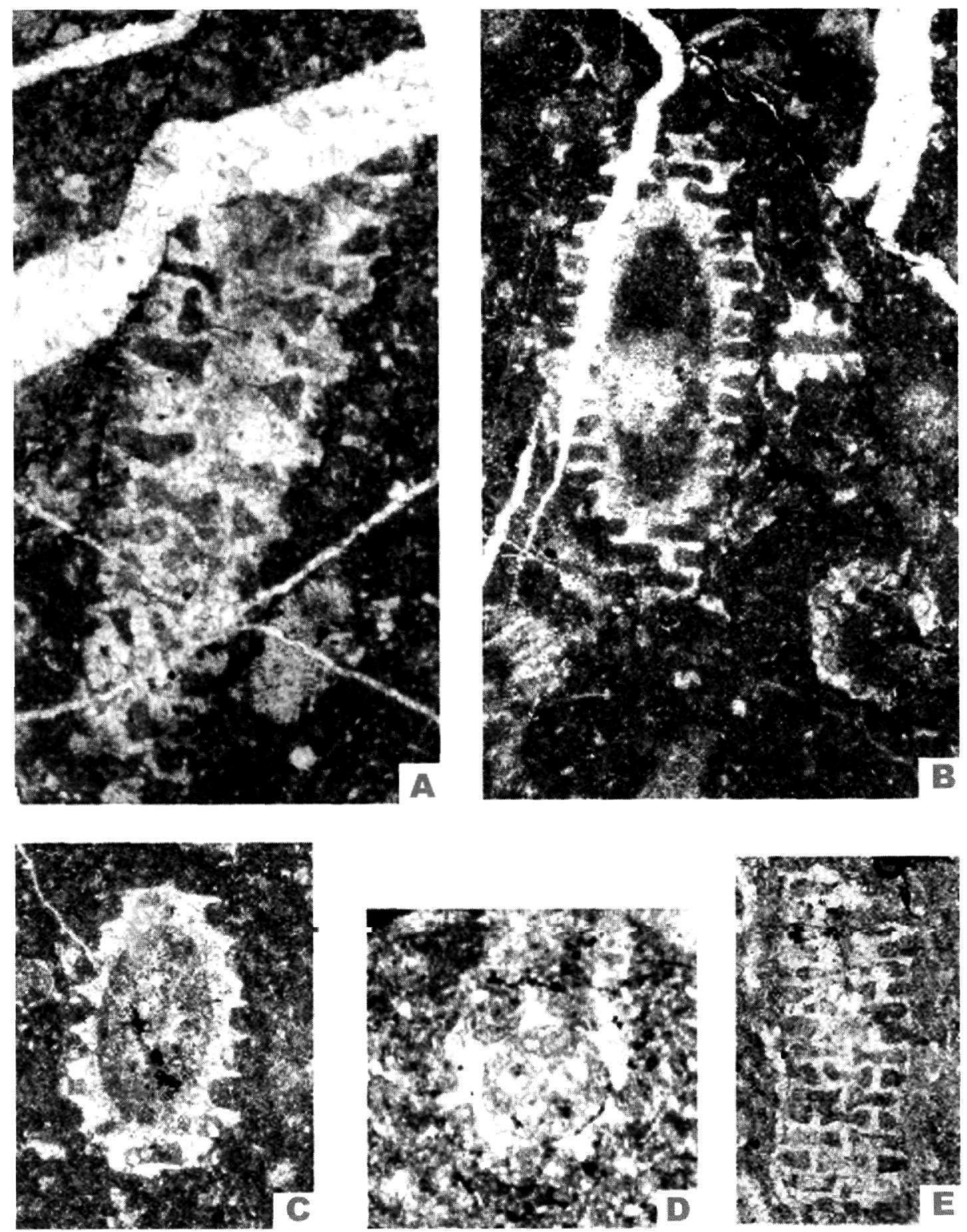

Figure 3 - Salpingoporella urladanasi Conrad, Peybernès \& Radoičić, tangential-oblique (A), oblique (B, C), horizontal (D) and tangential (E) sections, and charophytes (B), $x 45$. Tsimodia section, level 2, Early Aptian. A-D: sample NK.00.56. E: sample NK.00.66

- On the last conglomerate bed, the overlying thick-bedded neritic limestones contain again lumachelles with gastropods and/or bioclastic and fenestral mudstones deposited in a tidalflat environment. The presence of the dasyclad alga Likanella? hammudai Radoičić indicates a Turonian-Coniacian age (Radoičić 1975, Schlagintweit 1993, Ensslin and Schlagintweit 1999).

- Upwards, thin-bedded limestones are exposed, unfortunately recrystallized and not better determined, probably of deep sea environment; they are overlain by the flysch. 


\section{Discussion- Conclusion}

According to Beccaluva et al. (1984), the Vourinos ophiolite massif is interpreted as the product of a supra-subduction zone. The outcrops of radiolarites in this area, related to pillow lavas and marking the end of ocean spreading, are of Middle Jurassic age (Middle Bathonian - Early Callovian) on the basis of radiolaria determinations (Chiari et al. 2003). On the other hand, radiometric datations of the amphibolites at the base of the same ophiolite body gave $171 \pm 4 \mathrm{Ma}$ (Spray et al. 1984). This age pertains to a Late Bajocian intraoceanic hot thrust, doubling the oceanic crust/lithosphere (Chiari et al. 2003).

The age of the ophiolite nappe emplacement must be younger than Middle Jurassic (the age of the radiolarites). According to Vergely (1984), Photiades et al. (1998) and Photiades (2004), it took place probably during the Late Jurassic. Moreover, further information comes from the MiddleLate Jurassic carbonate platform body, tectonically overlying the ophiolites in the Rhodiani (Vourinos massif) area. The over-thrusting of this unit on the ophiolites is younger than the Late Kimmeridgian-Tithonian top of the carbonate platform limestones (Carras et al. 2004). In our opinion, both the over-thrusting of the ophiolites upon the pelagonian marbles and the local over-thrusting of the carbonate body upon the ophiolites took place during the same orogenetic event. The local carbonate body, being situated in the course of the ophiolite-nappe-advance, was detached from its substratum and then thrust upon the ophiolites. It is important to say that the detachment surface was not a stratigraphic surface. The first level we can observe upon the ophiolites in the wider Rhodiani area can be one of the four Jurassic levels described by Carras et al. (2004). In conclusion, the age of the thrusting seems best defined as Latest Jurassic.

The subsequent emersion of the Vourinos-Vermion area, starting from the Latest Jurassic, gave rise to a land, where the ophiolites, mainly serpentinites, suffered intense in situ lateritization, and the carbonates, in some parts of the Vourinos area, were karstified. The laterite materials contaminated the whole area, giving rise to primary or secondary ore deposits upon the erosional or karstic depressions.

The general modalities of the subsequent marine transgression upon the emerged area were substantially similar in the Vourinos and Vermion parts. The transgression started within the Barremian-Albian interval (more precisely Early Aptian at Vourinos), with the deposition of conglomerates and, laterally, with the development of a carbonate platform, firstly restricted, with deposition of brackish facies with Salpingoporella urladanasi, and then with normal salinity facies. The neritic sedimentation was stable until the Early Cenomanian. The following sedimentary history is similar, but not coeval, in the two areas: deepening, with pelagic and turbiditic carbonates and then flysch deposition. This deepening appears earlier at Vourinos, within the Cenomanian, just as in the Zyghosti area (see Carras et al. 2004) or probably at the Kteni locality, and later at Vermion, after the deposition of the Turonian-Coniacian neritic beds with Likanella? hammudai of the Koumaria section.

\section{Acknowledgments}

This study was financed by I.G.M.E. (Athens) for the Kteni and Koumaria sections and by MIUR 2000 (responsible: G. Principi) for the Tsimodia section. We are grateful to Prof. Dr. Fotini Pomoni-Papaioannou (Athens University) and Dr. Sebastian Lüning (Bremen University) for the critical reading of the manuscript.

\section{References}

Beccaluva, L., Ohnenstetter, D., Ohnenstetter, M., and Paupy, A., 1984. Two magmatic series with island arc affinities within the Vourinos ophiolite, Contrib. Mineral. Petrol. 85, 253-271. 
Bortolotti, V., Carras, N., Chiari, M., Fazzuoli, M., Marcucci, M., Photiades, A., and Principi, G., 2000. Decline and fall of an Upper Jurassic - Cretaceous carbonate platform, born (possibly) over wedging ophiolites: Vourinos- Pindos area, Northern Greece- Preliminary results. Abstract and Poster for the $80^{a}$ Riunione estiva della Soc. Geol. Italiana, Trieste, 6-8 Setembre, 93p.

Bortolotti, V., Carras, N., Chiari, M., Fazzuoli, M., Marcucci, M., Photiades, A., and Principi, G., 2001. Characteristics of the Upper Cretaceous transgression in the Kozani area (Pelagonian Domain, Northern Greece), Geoitalia 2001, $3^{\circ}$ Forum Italiano di Scienze della Terra, Chieti, 5-8 September, Abstracts, 547-548.

Bortolotti, V., Carras, N., Chiari, M., Fazzuoli, M., Marcucci, M., Photiades, A., and Principi, G., 2002. The Late Jurassic carbonate platform of Zyghosti, Vourinos-Pindos Zone, Northern Greece, VI International Symposium on the Jurassic System, Palermo, 12-22 September, Abstracts p. 21.

Bortolotti, V., Carras, N, Chiari, M., Fazzuoli, M., Photiades, A., and Principi, G., 2004. Sedimentary evolution of the Upper Jurassic Zyghosti platform, Kozani, Northern Greece, Proc. Int, Symp. Earth System Sciences 2004, Istanbul-Turkey, 705-712.

Braud, J., Brunn J.H., Campion, G., Didelot, J., Fourmaintraux, D., Lemaitre, J.-P., Mercier, L., Pichon, J.-F., and Vergely, P., 1984. La chaine du Vermion, ses nappes et sa bande broyée, Bull. Soc. Geol. France, (7), 26, 713-717.

Brunn, J.H., 1956. Contribution à l'étude géologique du Pinde septentrional et d'une partie de la Macédoine, Ann. Géol. Pays Hellén., 8, 1-258.

Brunn, J. H., 1982. Geological map of Greece 1:50.000, Piryoi Sheet, I.G.M.E.

Brunn, J. H., 1982. Geological map of Greece 1:50.000, Veroia Sheet, I.G.M.E.

Carras, N., Conrad, M., and Radoičić, R., in press. Salpingoporella, a common genus of Mesozoic Dasycladales (calcareous green algae), Revue de Paléobiologie, 25(2).

Carras, N., Fazzuoli, M., and Photiades, A., 2004. Transition from carbonate platform to pelagic deposition (Mid Jurassic-Late Cretaceous), Vourinos Massif, Northern Greece, Rivista Itaiana di Paleontologia e Stratigrafia, 110(1), 345-355.

Chiari, M., Bortolotti, V., Marcucci, M., Photiades, A., and Principi, G., 2003. The Middle Jurassic siliceous sedimentary cover at the top of the Vourinos ophiolite (Greece), Ofioliti, 28(2), 95-103.

Ensslin, R., and Schlagintweit F., 1999. Contributions to the knowledge of Upper Cretaceous calcareous algae from the central Middle Atlas mountains, Morocco, Z. dt. Geol. Ges., 149(4), 473-486.

Pichon, J.F., 1977. Une transversale dans la Zone Pélagonienne, depuis les collines de Krapa (SW) jusqu'au massif du Vermion (NE): Les premières séries transgressives sur les ophiolites), $6^{\text {th }}$ Colloquium on the Geology of the Aegean Region, Athens, 1, 163-171.

Pichon, J.F., and Lys, M., 1976. Sur l'existence d'une série du Jurassique à Crétacé inférieur surmontant les ophiolites, dans les collines de Krapa (massif du Vourinos, Grèce), C. R. Acad. Sci. Paris, 282, 523-524.

Photiades, A., 2004. Geological mapping revision of the Vermion Mountain (Internal Hellenides, Greece), Prodeedings of the $5^{\text {th }}$ International Symposium on Eastern Mediterranean Geology, Thessaloniki, 14-20 April, 1, 161-164.

Photiades, A., Skourtsis-Coroneou, V., and Grigoris, P., 1998. The stratigraphic and paleogeographic evolution of the eastern Pelagonian margin during the Late Jurassic - Creta- 
ceous interval (Western Vermion Mountain - Western Macedonia, Greece), Bull. Geol. Soc. Greece, 32(1), 71-77.

Radoičić, R., 1975. On Likanella hammudai sp. nov. from the Upper Cretaceous of the Tripoli area (Lybia) and the age of strata containing Dissocladella ondulata Raineri, Ann. Géol. Pénins. Balk., 39, 147-152.

Schlagintweit, F., 1993. Kretazische grünalgen aus Flachwassergesteinen der Nördlichen Kalkalpen: Ein Überblick, Zitteliana, 20, 123-132.

Spray, J.G., Bébien, J., Rex, D.C., and Roddick, J.C., 1984. Age constraints on the igneous and metamorphic evolution of the Hellenic-Dinaric ophiolites. In J.E. Dixon and A.H.F. Robertson (eds), The geological evolution of the Eastern Mediterranean. Geol. Soc. London, Spec. Pap., 17, 619-627pp.

Vergely, P., 1984. Tectonique des ophiolites dans les Hellénides internes. Conséquences sur l'évolution des régions téthysiennes occidentales. Thèse d'État Sc. Naturelles, Univ. ParisSud, Orsay, 649pp. 